\title{
Origin of the Plio-Pleistocene Vrica laminites: Organic geochemical evidence
}

\author{
Philip A. Meyers \\ Department of Geological Sciences and Center for Great Lakes and Aquatic Sciences, The University of Michigan, Ann \\ Arbor, MI 48109-1063, USA
}

(Received February 23, 1992; revision accepted August 12, 1993)

\begin{abstract}
Meyers, P.A., 1993. Origin of the Plio-Pleistocene Vrica laminites: Organic geochemical evidence. Mar. Geol., 115: 117-127.

Organic geochemical properties of samples from lower Pleistocene laminite Layer $\mathrm{H}$ at Vrica, Calabria, have been examined for evidence of the origin of these dark-colored sediments. The laminite samples are geochemically distinet from the surrounding gray marly clays. They contain less $\mathrm{CaCO}_{3}$ and more TOC, have higher $\mathrm{C} / \mathrm{N}$ ratios and lower $\delta^{13} \mathrm{C}$ values, and their hydrocarbon contents indicate larger proportions of land-derived organic matter. The Vrica laminites appear to have originated principally as a consequence of enhanced runoff of land-derived organic matter and clastic sediments from nearby land areas during episodes of wetter regional climate. Freshening of surface waters by the runoff created salinity stratification of the water column, diminished availability of oxygen in near-bottom waters, and improved preservation of organic matter. Marine productivity was probably also enhanced, but not as much as is evident for pelagic sapropels in the eastern Mediterranean.
\end{abstract}

\section{Introduction}

Multiple sapropel layers are found widely in the post-Messinian sedimentary record of the eastern Mediterranean Sea (e.g. Cita and Grignani, 1982; Thunell et al., 1984; Rossignol-Strick, 1985; Fontugne and Calvert, 1992). These organiccarbon-rich Pliocene-Quaternary deposits are best developed in deep-water settings. Neritic deposits similar in age to the pelagic sapropels exist as uplifted sections of alternating light-dark layered sediments but are generally not as rich in organic carbon. The origin of these "rhythmites" has been linked to local paleoclimatological factors. One hypothesis proposes that periods of monsoonally enhanced rainfall and ensuing increased delivery of nutrient-rich, sediment-laden river water to nearshore areas created the dark layers (Gudjonsson, 1987; De Visser et al., 1989; Weltje and De Boer, 1993). The intercalated light layers correspond to intervening dry periods of marine carbonate deposition. In an alternative explanation, periods of monsoonally enhanced upwelling and associated elevated marine productivity created the light layers (Thunell et al., 1991). The dark layers in this model represent the intervening dry periods. Although these two interpretations of the rhythmic bedding are contradictory, they both incorporate $20 \mathrm{kyr}$ cycles in paleoclimate driven by precessional changes in insolation to explain lower Pliocene rhythmites. The same precessional effect on rhythmic sediment deposition appears to continue into the Quaternary (e.g., RossignolStrick, 1983, 1985)

An example of shallow-water rhythmites for which a variety of sedimentological and micropaleontological information is available is the upper Pliocene-lower Pleistocene Vrica "laminites" of southern Italy. This exposure consists of intervals of dark-colored sediment within a sequence of gray, marly clays. The origin of these laminites has been attributed from isotopic and faunal evidence to periods of increased freshwater runoff from nearby land areas (Meulenkamp et al., 1979; Gudjonsson and Van der Zwaan, 1985; Howell et al., 1988). Dilution of the upper water column 
by freshwater is postulated to have intensified stratification of a nearshore basin and to have created poorly oxygenated or possibly anoxic bottom water conditions. Increased continental runoff also would have added land-derived organic matter and dissolved nutrients to ocean margin areas, the latter enhancing coastal productivity. The combination of terrigenous and marine organic matter would have magnified the delivery of organic matter to sediments, which would have diminished the availability of dissolved oxygen to benthic animals and further improved preservation of organic matter in the seafloor.

The type of organic matter contained in the sapropels can provide evidence about their origin. Changes in the proportions of organic matter derived from marine and continental sources is indicated by various molecular parameters, elemental compositions, and carbon isotope ratios. The presence or absence of anoxic conditions is suggested by molecular indicators of anaerobic bacteria. As examples, Ten Haven et al. (1987a,b,c) utilize a various kinds of molecular organic geochemical information to conclude that pelagic sapropels in the eastern Mediterranean originated from enhanced marine productivity, and Howell et al. $(1988,1990)$ employed isotopic and molecular compositions of the Vrica laminites to decide that fluvial contributions were responsible for the formation of their dark layers. In this paper, I expand on the organic geochemical contents of the Vrica section and discuss the relationship of these neritic deposits to those at other locations in the eastern Mediterranean Sea.

\section{Samples and analysis}

\section{Sampling area}

The Vrica laminite section is an uplifted exposure of the Crotone-Spartivento Basin located on the Marchesato Peninsula in Calabria, southern Italy (Fig. 1). The entire sequence is over $400 \mathrm{~m}$ in thickness and was rapidly deposited in the late Pliocene to early Pleistocene time (Tauxe et al., 1983). The sediments are believed to have been deposited at paleodepths ranging between 500 to $800 \mathrm{~m}$ in a nearshore basin (Selli et al., 1977).

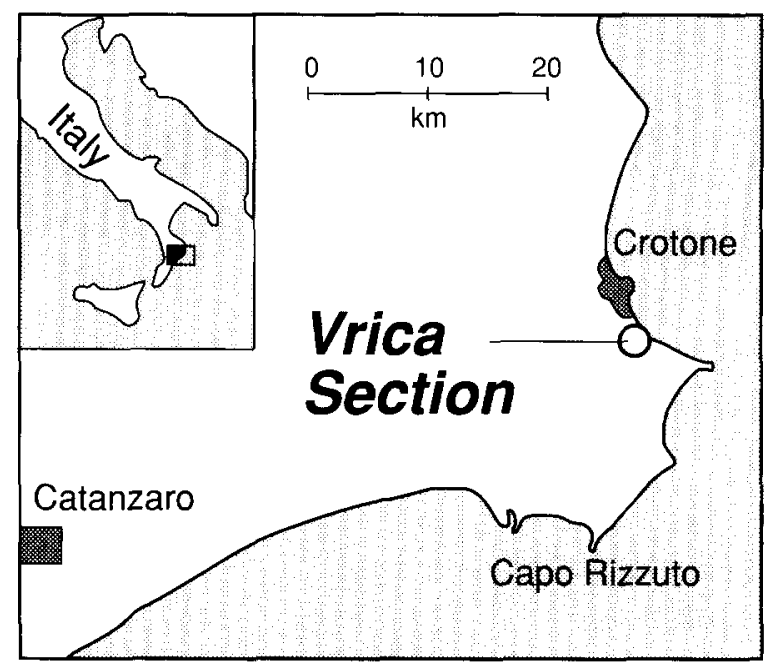

Fig. I. Location of the Vrica section on the Marchesato peninsula of Calabria, southern Italy.

Fourteen intervals of laminites occur in the upper $200 \mathrm{~m}$ of the sequence. These intervals are alphabetically labeled in ascending order (Selli et al., 1977). The Vrica section is especially significant inasmuch as it contains the stratotype Neogene/Quaternary boundary at the top of laminated unit E (Selli et al., 1977; Colalongo et al., 1982).

Six intervals from across lower Pleistocene laminite Layer $\mathrm{H}$ and its background gray marls were obtained for organic geochemical comparison. This single layer will be considered representative of the 14 laminite layers on the basis of the strong similarities documented in six different layers by Howell et al. (1990). The laminite layers evidently are mutually similar among themselves and consistently different from the gray marls with which they are associated.

\section{Analytical procedures}

Determinations of elemental and isotopic compositions were done by Howell et al. (1988, 1990) using standard procedures. Calcium carbonate concentrations were obtained by acid treatment of dried samples and quantification of the evolved $\mathrm{CO}_{2}$ by the gasometric method of Jones and Kaiteris (1983). Organic carbon concentrations and $\mathrm{C} / \mathrm{N}$ ratios were determined on acid-treated, 
carbonate-free samples using a Hewlett-Packard 185B CHN Analyzer. Concentrations have precisions of $\pm 0.05 \%$ in this procedure. Organic carbon $\delta^{13} \mathrm{C}$ values were determined by combustion of carbonate-free samples followed by measurement of the isotopic contents of the $\mathrm{CO}_{2}$ so produced with a VG Isogas SIRA-24 mass spectrometer. These values have precisions of $\pm 0.01 \%$ and are reported relative to the PDB standard (Epstein et al.. 1953) after the corrections of Craig (1957).

Hydrocarbons and fatty acids of four of the dried and ground samples of laminite layer $\mathrm{H}$ were extracted by Soxhlet reflux with a $1 / 1$ mixture of toluene/methanol for 24 hours. The extracts were concentrated, saponified with methanolic $\mathrm{KOH}$, and methylated with $\mathrm{BF}_{3}-\mathrm{MeOH}$ as described by Leenheer et al. (1984). Known amounts of $\mathrm{C}_{36} n$ alkane and of methyl heptadecanoate were added to each sample as internal standards prior to silica gel column chromatography. The hydrocarbon and fatty acid methyl ester fractions were analyzed using a Hewlett-Packard $5830 \mathrm{~A}$ gas chromatograph equipped with a $20 \mathrm{~m} \mathrm{SE}-54$ fused silica capillary column and a flame ionization detector. Hydrogen was the carrier gas. Quantities of individual hydrocarbon and fatty acid methyl ester components were determined by comparison to the known amounts of the internal standards after correcting for response factors and small amounts of laboratory contaminants.

\section{Results and discussion}

\section{Variations in $\mathrm{CaCO}_{3}$}

Calcium carbonate concentrations are consistently less in the dark layers than in the gray marls below and above them (Table 1). In their comparison of six of the Vrica laminite layers, Howell et al. (1990) show that the dark layers contain less $\mathrm{CaCO}_{3}$ than the super- and subjacent gray marls. Although the differences are small, typically approximately $4 \%$, lower carbonate concentrations seem to be a persistent feature of the Vrica laminites. This feature is also observed in the dark layers of rhythmites in lower Pliocene sections (e.g., De Visser et al., 1989; Thunell et al., 1991; Weltje and De Boer, 1993).

\section{Organic carbon concentrations}

The dark-colored samples have total organic carbon (TOC) concentrations about twice those of the light-colored marls (Table 1). Although the three upper Pliocene Vrica laminites studied by Howell et al. (1990) do not have TOC concentrations different from the marls, the three lower Pleistocene layers in their study display elevated concentrations. Howell et al. (1990) further show that the entire sequence averages approximately $0.5 \%$ TOC, which is notably higher than the values of ca. $0.2 \%$ typical of Quaternary deep-sea sediments (e.g. Keswani et al., 1984; Degens and Mopper, 1976). TOC concentrations of the Layer $\mathrm{H}$ samples are also provided on a carbonate-free basis to examine the possibility that the wholesediment TOC enhancements are caused by the lower $\mathrm{CaCO}_{3}$ contents of the laminites (Table 1). The carbonate-free TOC values of the laminites remain about twice those of the gray marls, implying actual increases in either the delivery or the preservation of organic matter to the laminites.

\section{Organic $C / N$ ratios}

$\mathrm{C} / \mathrm{N}$ ratios average 7.1 in samples of lightcolored marls close to Layer $\mathrm{H}$ and 10.6 within the layer itself (Table 1). $\mathrm{C} / \mathrm{N}$ ratios are crude but generally reliable indicators of the sources of organic matter (e.g., Meyers, in press). Differences in the proportions of the major classes of biochemical constituents of marine plants and land plants result in significant differences in the atomic $\mathrm{C} / \mathrm{N}$ ratios of these two principal origins of organic matter. Marine algae are relatively enriched in lipids and proteins; their $\mathrm{C} / \mathrm{N}$ ratios are consequently low. Land plants typically contain large proportions of woody and fibrous structural tissue made up of cellulose and lignin; their $\mathrm{C} / \mathrm{N}$ ratios are therefore high. Average ranges of $\mathrm{C} / \mathrm{N}$ values are 5 to 8 for marine organic matter and 20 to 100 for land material (cf. Emerson and Hedges, 1988; Jasper and Gagosian, 1989; Meyers, in press). Diagenesis of organic matter is known to modify $\mathrm{C} / \mathrm{N}$ values from their original values, but this effect is small and does not destroy their source 
TABLE 1

\begin{tabular}{|c|c|c|c|c|c|c|c|}
\hline \multirow{2}{*}{$\begin{array}{l}\text { Sample } \\
\text { Number }\end{array}$} & \multirow{2}{*}{$\begin{array}{l}\text { Section } \\
\text { Height (m) }\end{array}$} & \multirow[t]{2}{*}{ Color } & \multirow{2}{*}{$\begin{array}{l}\mathrm{CaCO}_{3} \\
(\%)\end{array}$} & \multicolumn{2}{|l|}{ TOC $(\%)$} & \multirow{2}{*}{$\begin{array}{l}\mathrm{C} / \mathrm{N} \\
\text { (atomic) }\end{array}$} & \multirow{2}{*}{$\begin{array}{l}\delta^{13} \mathrm{C} \\
\text { (organic) }\end{array}$} \\
\hline & & & & (whole sed.) & $\left(\mathrm{CaCO}_{3}\right.$-free $)$ & & \\
\hline $\mathrm{H}-6$ & 198.8 & light & 18.2 & 0.36 & 0.44 & 7.0 & -24.0 \\
\hline $\mathrm{H}-5$ & 198.0 & light & 14.4 & 0.54 & 0.63 & 8.7 & nd \\
\hline $\mathrm{H}-4$ & 197.7 & dark & 14.0 & 0.66 & 0.77 & 9.4 & -24.2 \\
\hline $\mathrm{H}-3$ & 197.2 & dark & 14.2 & 0.96 & 1.12 & 11.7 & -25.2 \\
\hline $\mathrm{H}-2$ & 196.8 & light & 17.2 & 0.28 & 0.34 & 5.7 & nd \\
\hline $\mathrm{H}-\mathrm{I}$ & 196.3 & light & 18.0 & 0.48 & 0.59 & nd & -23.9 \\
\hline
\end{tabular}

information (e.g., Jasper and Gagosian, 1989; Fontugne and Calvert, 1992; Meyers, in press).

The relatively low $\mathrm{C} / \mathrm{N}$ ratios found in the Layer $\mathrm{H}$ samples indicate that these sediments contain a mixture of marine and continental organic matter in which the marine fraction dominates. The elevation in the $\mathrm{C} / \mathrm{N}$ ratios found in the laminites suggests that larger proportions of land-derived organic matter occur in these dark layers than in the gray sediments surrounding them. Howell et al. (1990) show that $\mathrm{C} / \mathrm{N}$ ratios are similarly elevated in the six laminites distributed over the Vrica sequence, indicating that continental organic matter is enriched in all of these dark layers.

\section{Organic carbon isotopic compositions}

Organic carbon $\delta^{13} \mathrm{C}$ values average $-24 \%$ in the Layer $\mathrm{H}$ samples and are more negative for the two dark-layer samples than for the marls above and below the laminite layer (Table 1). Organic matter produced by modern plankton in the eastern Mediterranean has an average isotopic ratio of about $-22 \%$ (Fontugne and Calvert, 1992), whereas organic matter derived from typical continental C3 plants averages about $-26 \%$ (cf. Emerson and Hedges, 1988; Jasper and Gagosian, 1989; Meyers, in press). From these source signatures, the carbon isotopic values suggest that approximately half of the organic matter is from land plants in all four of these early Pleistocene samples and that slightly greater proportions of land-derived organic matter are found in the laminites than in the marls.
The isotopic evidence does not confirm the dominance of marine organic matter in the Layer $\mathrm{H}$ sediments indicated by the $\mathrm{C} / \mathrm{N}$ ratios. The carbon isotopic composition of planktonic organic matter is influenced by many factors-water temperature, species assemblage, concentration of dissolved $\mathrm{CO}_{2}$, to name a few. Moreover, diagenesis can cause isotopic shifts of up to 1 to $2 \%$ in sedimentary organic matter (e.g., Fontugne and Calvert, 1992; Meyers, in press), which covers the range of the isotope values of the Layer $\mathrm{H}$ samples (Table 1). For these reasons, these data must be interpreted cautiously, and it is probable that the majority of the organic matter in these marine sediments is from neritic organisms.

The isotopic shift towards more negative $\delta^{13} \mathrm{C}$ values in the dark sediments agrees, however, with the increased contributions of land-derived material signaled by the $\mathrm{C} / \mathrm{N}$ ratios. The shift could arise simply from greater proportions of continental plant debris in the organic matter, or it could result from the dilution of coastal waters by river water containing isotopically light dissolved $\mathrm{CO}_{2}$. Effects of the latter process have been noted as lighter $\delta^{13} \mathrm{C}$ and $\delta^{18} \mathrm{O}$ values in carbonates produced by planktonic foraminifera in both lower and upper Pliocene laminites from southern Italy (Gudjonsson and Van der Zwaan, 1985; Gudjonsson, 1987).

The change to lighter values evident in the darkcolored, lower Pleistocene neritic sediments is similar to the organic carbon isotopic compositional patterns in upper Pleistocene deep-water sapropels in the eastern Mediterranean. Fontugne and 
Calvert (1992) report that the $\delta^{13} \mathrm{C}$ values of bulk organic matter in the sapropelic layers are consistently lighter than in intercalated oozes. The shift is of greater magnitude in the pelagic sediments, however, reaching as much as $6 \%$. They interpret the lighter values to reflect periodic freshwater flooding of the eastern Mediterranean. They furthermore conclude that the organic carbon enrichments of the deep-water sapropels originate from enhanced preservation of marine organic matter.

\section{Extractable hydrocarbons and fatty acids}

Comparison of the compositions of extractable alkanes and $n$-alkanoic acids from two laminite samples and two gray marl samples shows interesting patterns (Table 2). Concentrations of $n$ alkanes are substantially larger than those of $n$ alkanoic acids. Fatty acids typically are much more abundant than hydrocarbons in organisms and consequently in most sediments. The reversal in relative abundances of these two lipid fractions implies that the organic matter in the Vrica section has been heavily microbially degraded and the fatty acid fraction has been preferentially destroyed, inasmuch as $n$-alkanes are generally more resistant to degradation than are fatty acids.

Biologically produced hydrocarbons and fatty acids have characteristic carbon chainlengths. An odd number of carbon atoms is found in the $n$ alkanes of most organisms, whereas the number of carbon atoms in their $n$-alkanoic acids is even (e.g., Simoneit, 1986). After burial in sediments, diagenetic modifications of alkanes and alkanoic acids diminishes their carbon chainlength specificity. The carbon preference index (CPI) has been devised to indicate the extent of diagenetic modification that has occurred to $n$-alkanes and $n$-alkanoic acids (Bray and Evens, 1961; Cooper and Bray, 1963). High CPI values ( $>5$ ) indicate good preservation of original compositions, whereas low values $(\sim 1)$ indicate loss of chainlength specificity as a result of extensive diagenetic alteration. The relatively low CPI values of the $n$-alkanes (Table 2) support the hypothesis that substantial microbial reworking of this lipid fraction has occurred. Even greater microbial alteration of the fatty acid components would be expected, yet their CPI values are relatively high (Table 2 ). The higher CPI values of the $n$-alkanoic acids probably reflects substitution of secondary, microbial fatty acids for those of the initially sedimented organic matter.

The $n$-alkane distributions in Fig. 2 are dominated by the $\mathrm{C}_{17}$ component diagnostic of phytoplankton (cf. Blumer et al., 1971), which indicates that most of the hydrocarbon fraction is marine in origin. Because neither hydrocarbons nor fatty acids constitute more than a few percent of the total organic matter, dominance of the $n$-alkane distributions by algal components does not necessarily signify that most of the organic matter preserved in the seabottom arises from a marine source. However, the very strong $n-\mathrm{C}_{17}$ dominance

\section{TABLE 2}

Comparison of extractable hydrocarbon and fatty acid compositions of dark laminites and surrounding gray marl in lower Pleistocene Layer $\mathrm{H}$ at Vrica. Concentrations are given in milligrams total $n$-alkanes or $n$-alkanoic acids per gram organic carbon. CPI represents carbon preference index, or the ratio of odd-toeven $n$-alkanes or even-to-odd $n$-alkanoic acids. Short/long ratios indicate the predominance of aquatic/continental alkanes or acids. $\mathrm{Pr} / \mathrm{Ph}$ is the ratio of pristane to phytane, two isoprenoid aliphatic hydrocarbons

\begin{tabular}{|c|c|c|c|c|c|c|c|c|}
\hline \multirow{2}{*}{$\begin{array}{l}\text { Sample } \\
\text { Number }\end{array}$} & \multirow[t]{2}{*}{ Color } & \multicolumn{3}{|c|}{ n-Alkanes } & \multirow[t]{2}{*}{$\mathrm{Pr} / \mathrm{Ph}$} & \multicolumn{3}{|c|}{ n-Alkanoic acids } \\
\hline & & $\mathrm{mg} / \mathrm{gC}$ & CPI & short/long ${ }^{1}$ & & $\mathrm{mg} / \mathrm{gC}$ & CPI & short/long ${ }^{2}$ \\
\hline $\mathrm{H}-6$ & light & 2.38 & 1.83 & 15.24 & 2.43 & 0.25 & 7.10 & 2.10 \\
\hline $\mathrm{H}-4$ & dark & 0.80 & 1.75 & 4.70 & 2.36 & 0.18 & 5.61 & 3.05 \\
\hline $\mathrm{H}-3$ & dark & 0.55 & 1.74 & 7.51 & 2.13 & 0.21 & 4.09 & 0.93 \\
\hline $\mathrm{H}-2$ & light & 2.79 & 1.74 & 13.49 & 2.56 & 0.41 & 13.50 & 9.67 \\
\hline
\end{tabular}

${ }^{1}\left(\mathrm{C}_{17}+\mathrm{C}_{19}+\mathrm{C}_{21}\right) /\left(\mathrm{C}_{27}+\mathrm{C}_{29}+\mathrm{C}_{31}\right) \cdot{ }^{2}\left(\mathrm{C}_{14}+\mathrm{C}_{16}+\mathrm{C}_{16}+\mathrm{C}_{18}\right) /\left(\mathrm{C}_{24}+\mathrm{C}_{26}+\mathrm{C}_{28}\right)$. 

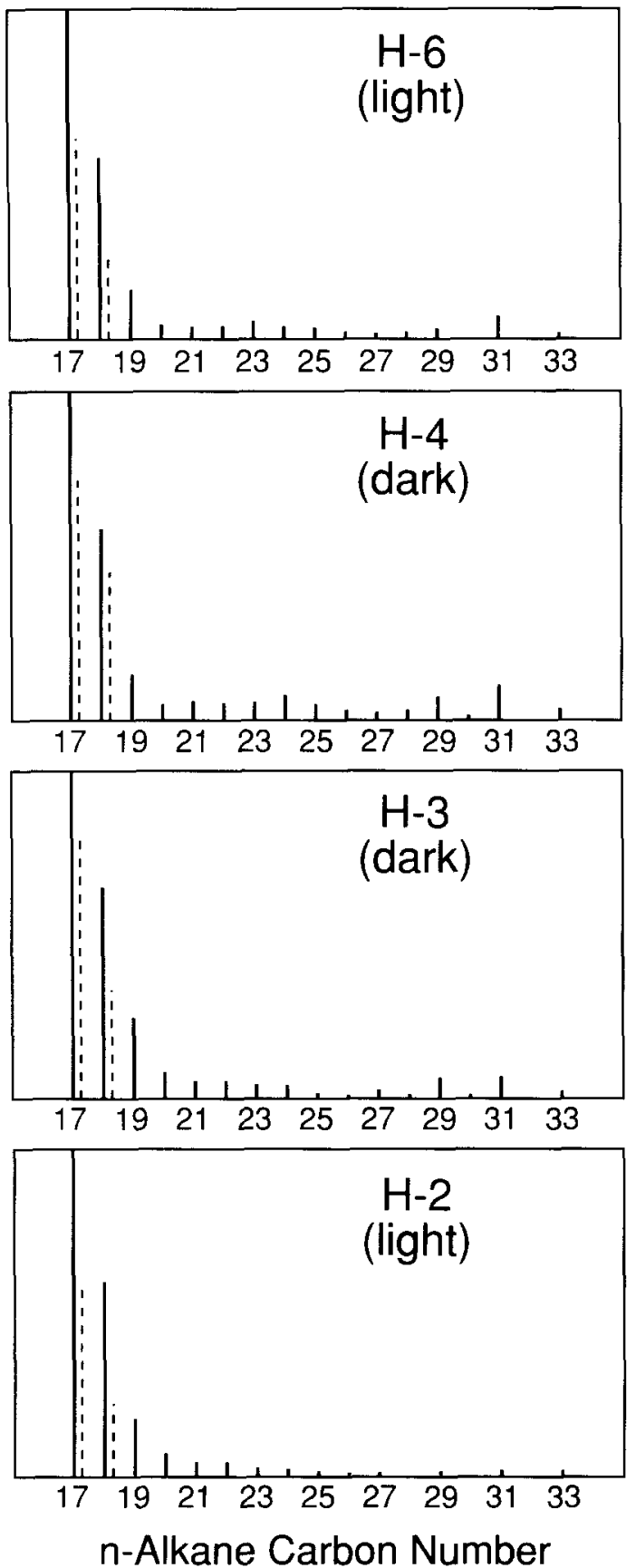

Fig. 2. Distributions of $n$-alkanes and the isoprenoids pristane and phytane (dotted lines) in extracts from four lower Pleistocene Vrica samples. Contributions of each component are shown relative to the major component, $n-\mathrm{C}_{17}$ in all four cases. seen in Fig. 2 is persuasive evidence that marine productivity was generally high in the paleoCrotone-Spartivento Basin during the early Pleistocene. Moreover, the strong algal contribution to the hydrocarbon distributions agrees with the relatively low $\mathrm{C} / \mathrm{N}$ values (Table 1) in suggesting that marine material comprises the majority of the organic matter in the Vrica laminites.

Several features of the hydrocarbon fraction indicate that the proportion of land-derived organic components is greater in the laminites than in the light-colored marls. Concentrations of total $n$-alkanes relative to total organic carbon in the laminite samples are approximately one-fourth those of the gray marls (Table 2), suggesting replacement of lipid-rich algal organic matter by cellulose-rich continental material, which is a change in organic matter character that is supported by the higher $\mathrm{C} / \mathrm{N}$ values in the laminites (Table 1). This change is accompanied by lower ratios of the short chainlength, algal $n$-alkanes to the long chainlength $n$-alkanes indicative of landplant waxes (e.g., Rieley et al., 1991). The lower short/long ratios in the dark-colored samples reflect delivery of greater proportions of landderived $n$-alkanes during deposition of the laminite layers in this near-coastal setting.

The $n$-alkanoic acid compositions do not show the same types of source changes seen in the $n$ alkanes because of the probable microbial reworking of the fatty acids, which would be more extensive than for the hydrocarbons. Long-chain $n$-alkanoic acids diagnostic of land-plant waxes are nonetheless major components of the fatty acid distributions of three of the four Layer $\mathrm{H}$ samples (Fig. 3). The $\mathrm{C}_{26}, \mathrm{C}_{28}$, and $\mathrm{C}_{30} n$-acids are probably survivors of organic matter recycling, inasmuch as shorter-chain components are more susceptible to microbial degradation. The presence of these land-plant fatty acids is additional evidence that land-derived organic matter was delivered to these nearshore sediments.

High amounts of pristane, the isoprenoid hydrocarbon formed from chlorophyll $a$ in the gut of calanoid copepods (e.g., Blumer et al., 1961), relative to $n-\mathrm{C}_{17}$ (Fig. 2) are further support for major inputs of marine hydrocarbons in the Vrica section. The ratio of pristane to phytane, another isopren- 

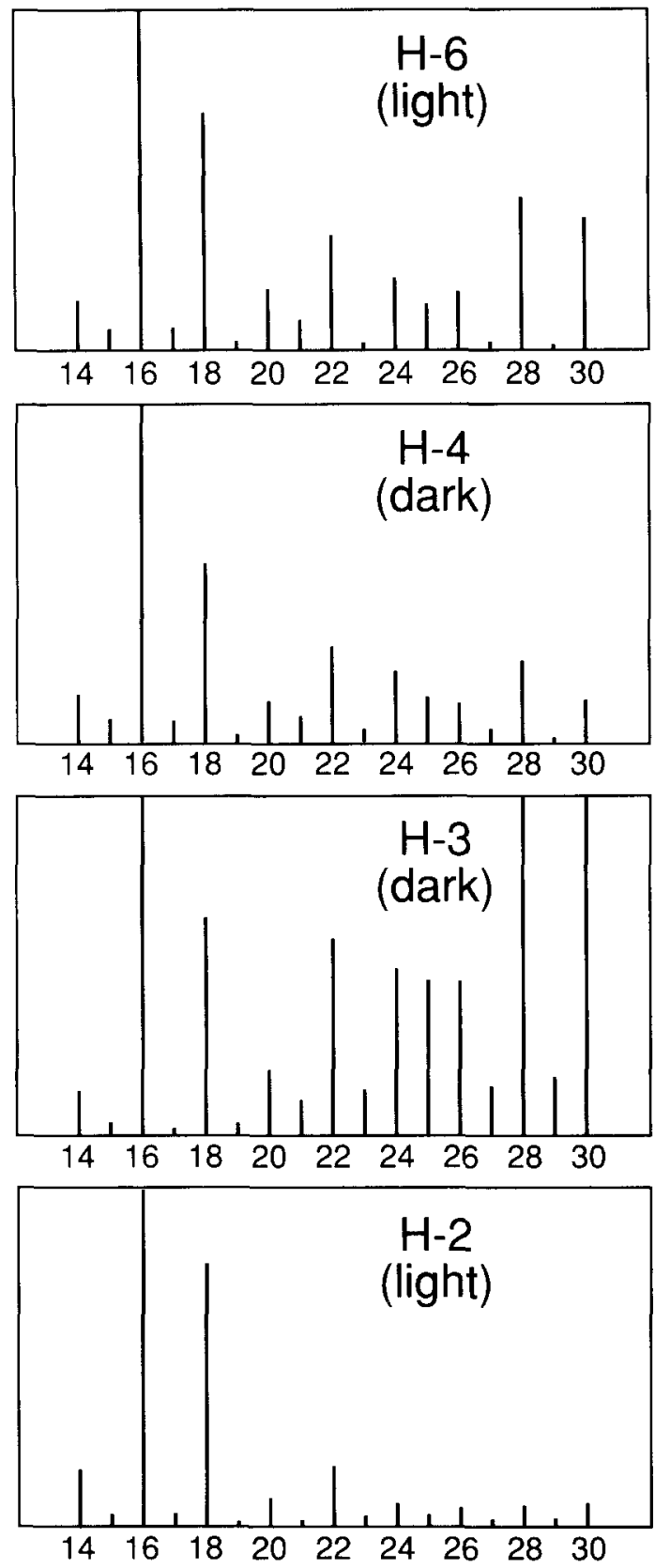

\section{n-Alkanoic Acid Carbon Number}

Fig. 3. Distributions of $n$-alkanoic acids in extracts from four lower Pleistocene Vrica samples. Contributions of each acid are shown relative to the major component, $n-\mathrm{C}_{16.0}$ in all four cases.

oid hydrocarbon but one which is believed to be derived from chlorophyll $a$ during methanogenesis in sediments (cf. Risatti et al., 1984), is often employed as an indicator of sedimentary paleo- environment. A pristane/phytane ratio of $2-3$ is typical of clastic sediments deposited in normal, oxygenated marine areas, whereas values of less than one indicate anoxic conditions (Didyk et al., 1978). Pristane/phytane ratios remain relatively high throughout both the light and dark intervals of Layer $\mathrm{H}$ (Table 2), which is expected for marly clays and which argues against anoxic bottom waters. The pristane/phytane ratios in both dark samples, however, are slightly lower than those in the marls and may indicate that some partial oxygen limitation existed during the period of laminite deposition.

\section{Foraminiferal compositions}

Planktonic faunal compositions differ between the laminites and the non-laminated Vrica sediments. Higher proportions of Neogloboquadrina dutertre $i$ within the laminites indicate that nutrient concentrations were elevated in the photic zone, and dilution of the ocean surface by isotopically light freshwater is indicated by lower $\delta^{18} \mathrm{O}$ values of planktonic foraminifera (Howell et al., 1990). Both differences suggest that the laminites were deposited during periods of increased runoff from nearby land areas. Furthermore, Howell et al. (1990) note that the dextral-coiled form of Neogloboquadrina pachyderma is more abundant than the sinistral form in the laminites. This difference indicates that surface water temperatures were somewhat warmer during the deposition of the laminite layers than during marl sedimentation (Reynolds and Thunell, 1986).

Benthic foraminifera appear to be absent, or at least rare, in the laminite layers (Howell et al., 1990). The preservation of laminations in sediments generally reflects the absence of mixing by benthic macrofauna. The paucity of benthic forams and the presence of laminations indicate that bottom waters were anoxic, or at least oxygen deficient, during the times of laminite deposition in the early Pleistocene. A possible cause of oxygen depletion is salinity stratification of the coastal water column by increased land runoff (Meulenkamp et al., 1979; Gudjonsson and Van der Zwaan, 1985; Howell et al., 1988), and this 
has also been postulated as an important factor in early Pliocene rhythmites (Gudjonsson, 1987).

\section{Paleoceanographic origin of the Vrica laminites}

Absolute ages have not been determined on the Vrica section. Calculations of sediment mass accumulation rates are consequently not available to determine whether the laminites represent periods of increased or decreased sedimentation. The lack of good age control also prevents definite coupling of the laminite intervals to times of solar precession. These problems similarly confound explanation of other post-Messinian rhythmites in the eastern Mediterranean. Inferences can nonetheless be drawn from the available data, and a reasonable hypothesis about the origin of the Vrica laminites can be made.

The laminites are geochemically distinct from the surrounding marly clays. They contain less $\mathrm{CaCO}_{3}$ and more TOC, have higher $\mathrm{C} / \mathrm{N}$ ratios and lower $\delta^{13} \mathrm{C}$ values, and their hydrocarbon contents differ in concentration and composition. These data provide important paleoceanographic inferences about the origin of the laminite layers.

Variations in calcium carbonate concentrations result from three main processes. The first factor involves dilution of carbonates by opaline or clastic components. A second possible origin of the carbonate fluctuations is from variations in paleoproduction of carbonates as marine productivity or planktonic species assemblages changed. The third possibility is that they represent alternations in rates of dissolution of carbonate sediment particles during sinking or on the seafloor. Carbonate dissolution in relatively shallow water depths like those postulated to have existed in the Crotone-Spartivento Basin would be driven principally by in situ decomposition of marine organic matter (cf. Berger, 1970; Thunell, 1976; Emerson and Bender, 1982; Diester-Haass et al., 1986). Such dissolution requires strongly anoxic, sulfatedepleted conditions which would accommodate methanogenic activity. The activity of these bacteria appears to be depressed until interstitial sulfate is depleted (Claypool and Kvenvolden, 1983). Pristane/phytane ratios of 2-3 (Table 2) rule out much methanogenesis and consequently make in situ dissolution an unlikely factor in decreasing the carbonate concentrations of the laminites.

In Vrica laminite Layer $\mathrm{H}$, a doubling of organic carbon concentrations is accompanied by an inferred increase in the land-derived character of the organic matter. It is probable that a similar although non-quantifiable increase occurred in the delivery of clastic sediments from land, thereby diluting the carbonate contents of the laminite layers and increasing the sedimentation rate. Although increases in the proportion of $N$. dutertrei indicate enhanced nutrient availability in the surface waters, a concomitant increase in the delivery of marine organic matter to the sediments is not evident. A small increase could have occurred, however. If virtually all of the marine organic matter were oxidized at the seafloor, bottom-water oxygen may have become depleted.

The probable scenario which was involved in formation of the laminites is an increase in runoff of freshwater from the nearby land, which added land-derived organic matter and clastic components to sediments on the basin floor and simultaneously created a salinity-stratified water column. Diminished circulation within the basin eventually established oxygen-depleted conditions at the seafloor, eliminating benthic fauna and improving preservation of organic matter in the dark-colored laminites.

Howell et al. (1988) previously concluded that freshwater runoff and consequent density stratification of the water column was the principal cause of the laminites at Vrica. They further demonstrate that delivery of land-derived organic matter was critical to organic carbon enrichment of the laminites at Gela, Sicily. A similar scenario has been proposed to explain a late Pleistocene-Holocene sapropel layer found in the Aegean Sea in which terrigenous organic matter is abundant (Cramp et al., 1988). In contrast, diatom-rich laminites at Bianco, southern Calabria, record episodes of runoff-enhanced marine productivity (Howell et al., 1988). These observations illustrate that different types of land runoff can contribute (1) clastic components, which dilute marine sediments, (2) detritus from land plants, which adds to sediment organic matter concentrations, and (3) dissolved nutrients, which enhances marine productivity. 
Depending on the specific conditions in the land areas which are the sources of the runoff, there can be different, localized consequences on the sediments and rates of marine productivity in nearshore basins.

The Vrica laminite sequence shares several features with the deep-water sapropels of the eastern Mediterranean Sea. Oxygen isotope compositions of planktonic foraminifera indicate that surface seawater had diminished salinity at the times of laminite deposition (Howell et al., 1988) and also during sapropel formation (Thunell et al., 1984; Ganssen and Troelstra, 1987). Both nearshore and pelagic laminated sediments evidently record periods of wetter climate and greater river flow into the Mediterranean. Solar precession has probably been the cause of the climate fluctuations responsible for both the coastal and deep-water organic-carbon-rich sediments (Rossignol-Strick, 1985; Gudjonsson, 1987; De Visser et al., 1989; Weltje and De Boer, 1993). The laminites at Vrica and the sapropel layers deposited at different periods of time similarly vary in TOC contents, $\mathrm{CaCO}_{3}$ concentrations, and microfossil characteristics (e.g., Howell et al., 1990; Ten Haven et al., 1987a). Increased $\mathrm{C} / \mathrm{N}$ ratios also occur in both the laminites and in the sapropel layers (Sigl et al., 1978; Fontugne and Calvert, 1992), indicating that both contain enhanced proportions of land-derived organic matter. Moreover, Ten Haven et al. (1987b) show that the proportion of land-derived organic matter in deep-water sapropel layer $S_{1}$ increases away from shore because marine productivity was enhanced closer to fluvial sources of nutrients. Paleoenvironmental conditions evidently varied both geographically and temporally. An example of variation with time is provided by Thunell et al. (1984), who found that deep-water sapropels deposited in the Pliocene do not contain the light $\delta^{18} \mathrm{O}$ values which indicate low surface salinities in Pleistocene sapropels. The inferred absence of salinity stratification in the Pliocene suggests that Mediterranean deep circulation must have been very sluggish to enable sapropel deposition at this time.

The general picture that emerges from comparison of the Vrica laminites and the pelagic sapropels is that the Plio-Pleistocene was a period of episodic freshening of the surface waters of the Mediterranean, particularly in coastal areas. The circulation of this sea was probably estuarine, with surface waters flowing to the Atlantic, which is opposite to the Holocene circulation. As postulated by Stanley et al. (1975), the dissolved oxygen contents of the bottom waters in the eastern basins of the Mediterranean would have been sensitive to episodes of retarded water movement and of enhanced delivery of organic matter. The Crotone-Spartivento Basin in which the Vrica sequence was deposited would have been one of many coastal basins which were similarly sensitive to such episodes.

\section{Summary and conclusion}

Increases in the proportion of land-derived organic matter and absence of significantly elevated organic carbon concentrations in the Vrica laminites indicate that episodes of increased land runoff contributed organic matter from nearby land areas and created salinity stratification of the coastal basins during the late Pliocene and early Pleistocene. Bottom-water oxygen became limited during times of salinity stratification of the restricted nearshore paleo-Crotone-Spartivento Basin. The absence of abundant oxygen depressed benthic faunal activity and lead to sediment lamination and improved preservation of organic matter. Clastic sediment components diluted the marine carbonate contents of the dark-colored laminites. These climate-induced changes in marine conditions evidently occurred at $20 \mathrm{kyr}$ precessional cycles at many locations in the eastern Mediterranean Sea.

\section{Acknowledgments}

I thank M. Howell and R. Thunell for providing samples from Vrica Layer H. K.H. Dunham assisted in the hydrocarbon and fatty acid analyses. Aspects of this research were supported by a NATO Research Collaboration Grant.

\section{References}

Berger, W.H., 1970. Planktonic foraminifera: Selective solution and the lysocline. Mar. Geol., 8: 111-138. 
Blumer, M., Mullin, M.M. and Thomas, D.S., 1963. Pristane in zooplankton. Science, 140: 974.

Blumer, M., Guillard, R.R.L. and Chase, T., 1971. Hydrocarbons of marine phytoplankton. Mar. Biol., 8: 183-189.

Bray, E.E. and Evans, E.D., 1961. Distribution of $n$-paraffins as a clue to recognition of source beds. Geochim. Cosmochim. Acta, 22: 2-15.

Cita, M.B. and Grignani, D., 1982. Nature and origin of late Neogene Mediterranean sapropels. In: S.O. Schlanger and M.B. Cita (Editors), Nature and Origin of Cretaceous Carbon-rich Facies. Academic Press, New York, pp. $165-196$.

Claypool, G.E. and Kvenvolden, K.A., 1983. Methane and other hydrocarbon gases in marine sediment. Ann. Rev. Earth Planet. Sci.. 11: 299-327.

Colalongo, M.L., Pasini, G., Pelosio, G., Raffi, S., Rio, D., Ruggieri, G., Sartoni, S., Selli, R. and Sprovieri, R., 1982. The Neogene/Quaternary Boundary definition: a review and proposal. Geogr. Fis. Din. Quat., 5: 59-68.

Cooper, J.E. and Bray, E.E., 1963. A postulated role of fatty acids in petroleum formation. Geochim. Cosmochim. Acta, 27: $1113-1127$.

Craig, H., 1957. Isotopic standards for carbon and oxygen and correction factors for mass spectrometric analysis of carbon dioxide. Geochim. Cosmochim. Acta, 12: 133-149.

Cramp, A., Collins, M. and West, R., 1988. Late Pleistocene-Holocene sedimentation in the NW Aegean Sea: A palaeoclimatic palaeoceanographic reconstruction. Palaeogeogr., Palaeoclimat., Palaeoecol., 68: 61-77.

Degens, E.T. and Mopper, K., 1976. Factors controlling the distribution and early diagenesis of organic material in marine sediments. In: J.P. Riley and R. Chester (Editors), Chemical Oceanography. Academic Press, New York, 6 , pp. 59-113.

De Visser, J.P., Ebbing, J.H.J., Gudjonsson, L., Hilgen, F.J., Jorissen, F.J., Verhallen, P.J.J.M. and Zevenboom, D., 1989. The origin of rhythmic bedding in the Pliocene Trubi Formation of Sicily, southern Italy. Palaeogeogr., Palaeoclimatol., Palaeoecol., 69: 45-66.

Didyk, B.M., Simoneit, B.R.T., Brassell, S.C. and Eglinton, G., 1978. Geochemical indicators of paleoenvironmental conditions of sedimentation. Nature, 272: 216-222.

Diester-Haass, L., Meyers, P.A. and Rothe, P., 1986. Light-dark cycles in opal-rich sediments near the PlioPleistocene boundary, DSDP Site 532, Walvis Ridge Continental Terrace. Mar. Geol., 73: 1-23.

Emerson, S. and Hedges, J.I., 1988. Processes controlling the organic carbon content of open ocean sediments. Paleoceanography, 5: 685-707.

Epstein, S., Buchsbaum, R., Lowenstam, H.A. and Urey, H., 1953. Revised carbonate-water isotopic temperature scale. Geol. Soc. Am. Bull., 64: 1315-1326.

Fontugne, M.R. and Calvert, S.E., 1992. Late Pleistocene variability of the carbon isotopic composition of organic matter in the eastern Mediterranean: Monitor of changes in carbon source and atmospheric $\mathrm{CO}_{2}$ concentrations. Paleoceanography, $7: 1-20$.

Ganssen. G. and Troelstra, S.R., 1987. Paleoenvironmental changes from stable isotopes in planktonic foraminifera from eastern Mediterranean sapropels. Mar. Geol., 75: 221-230.

Gudjonsson, L., 1987. Local and global effects the Early Pliocene Mediterranean stable isotope records. Mar. Micropaleontol., 12: 241-253.

Gudjonsson, L. and Van der Zwaan, G.J., 1985. Anoxic events in the Pliocene Mediterranean: Stable isotope evidence of run-off. Proc. K. Ned. Akad. Wet., Ser. B, 88: 69-82.

Howell, M.W., Thunell, R., Tappa, E., Rio. D. and Sprovieri, R., 1988. Late Neogene laminated and opal-rich facies from the Mediterranean region: Geochemical evidence for mechanisms of formation. Palaeogeogr., Palaeoclimatol., Palaeoecol., 64: 265-286.

Howell, M.W., Rio, D. and Thunell, R., 1990. Laminated sediments from the Vrica Section, (Calabria, S. Italy): evidence for Plio-Pleistocene climatic change in the Mediterranean region. Palaeogeogr., Palaeoclimatol., Palaeoecol., 78: 195-216.

Jasper, J.P. and Gagosian, R.B., 1989. Glacial-interglacial climatically forced $\delta^{13} \mathrm{C}$ variations in sedimentary organic matter. Nature, 343: 60-62.

Jones, G.A. and Kaiteris, P., 1983. A vacuum gasometric technique for rapid and precise analysis of calcium carbonate in sediments. J, Sediment. Petrol., 53: 655-660.

Keswani, S.R., Dunham, K.W. and Meyers, P.A., 1984. Organic geochemistry of late Cenozoic sediments from the subtropical South Atlantic. Mar. Geol., 61: 25-42.

Leenheer, M.J., Flessland, K.D. and Meyers, P.A., 1984. Comparison of the lipid character of sediments from the Great Lakes and the northwestern Atlantic. Org. Geochem.. 7: $141-150$.

Meulenkamp, J.E., Driever, B.W.M., Jonker, H.A., Spaak, P., Zachariasse, W.J. and Van der Zwaan, G.J., 1979. Late Miocene-Pliocene climatic fluctuations and marine "cyclic" sedimentation patterns. Ann Geol. Pays Hellen., Tome Hors Ser., 2: 831-842

Meyers, P.A., 1993. Preservation of source identification of sedimentary organic matter during and after deposition. Chem. Geol., in press.

Reynolds, L. and Thunell, R.C., 1986. Seasonal production and morphologic variation of Neogloboquadrina pachyderma in the Northeast Pacific. Micropaleontology, 32: 1-18.

Rieley, G., Collier, R.J., Jones, D.M. and Eglinton, G., 1991. The biogeochemistry of Ellesmere Lake, U.K.-I: source correlation of leaf wax inputs to the sedimentary lipid record. Org. Geochem., 17: 901-912.

Risatti, J.B., Rowland, S.J., Yon, D. and Maxwell, J.R., 1984. Stereochemical studies of acyclic isoprenoids-XII. Lipids of methanogenic bacteria and possible contributions to sediments. In: P.A. Schenck and J.W. de Leeuw (Editors), Advances in Organic Geochemistry 1983. Pergamon. Oxford, pp. 93-103.

Rossignol-Strick, M., 1983. African monsoons, an immediate response to orbital insolation. Nature, 304: 46-49.

Rossignol-Strick, M., 1985. Mediterranean Quaternary sapropels, an immediate response of the African monsoon to variation of insolation. Palaeogeogr., Palaeoclimatol., Palaeoecol., 49: 237-263.

Selli, R., Accorsi, C.A., Nazzanti, M., Carchetti, D., Bigazzi, G., Bonadonna, F.P., Borsetti, A.M., Cati, F., Colalongo, 
M.L., d’Onofrio, S., Landini, W., Menesini, E., Mezetti, R., Pasini, G., Savelli, C. and Tampieri, R., 1977. The Vrica section (Calabria, Italy): a potential Neogene/Quaternary boundary stratotype. G. Geol., 42: 181-204.

Sigl, W., Chamley, H., Fabricius, F., Giroud d'Argoud, G. and Müller, J., 1978. Sedimentology and environmental conditions of sapropels. Init. Rep. DSDP, 42: 445-465.

Simoneit, B.R.T., 1986. Biomarker geochemistry of black shales from Cretaceous oceans-An overview. Mar. Geol., 70: 9-41.

Stanley, D.J., Maldonado, A and Stuckenrath, R., 1975. Strait of Sicily depositional rates and patterns, and possible reversal of currents in the late Quaternary. Palaeogeogr., Palaeoclimatol., Palaeoecol., 18: 279-291.

Tauxe, L., Opdyke, N.D., Pasini, G. and Elmi, R.J., 1983. Age of the Plio-Pleistocene boundary in the Vrica section, southern Italy. Nature, 304: 125-129.

Ten Haven, H.L., Baas, M., Kroot, M., De Leeuw, J.W., Schenck, P.A. and Ebbing, J., 1987a. Late Quaternary Mediterranean sapropels. III: Assessment of source of input and palaeotemperature as derived from biological markers. Geochim. Cosmochim. Acta, 51: 803-810.

Ten Haven, H.L., Baas, M., De Leeuw, J.W., Schenck, P.A. and Brinkhuis, H., 1987b. Late Quaternary Mediterranean sapropels II. Organic geochemistry and palynology of $S_{1}$ sapropels and associated sediments. Chem. Geol., 64: 149-167.

Ten Haven, H.L., Baas, M., De Leeuw, J.W. and Schenck, P.A., 1987c. Late Quaternary Mediterranean sapropels, IOn the origin of organic matter in sapropel $S_{7}$. Mar. Geol., 75: $137-156$.

Thunell, R.C., 1976. Calcium carbonate dissolution history in Late Quaternary deep-sea sediments, western Gulf of Mexico. Quat. Res., 6: 281-297.

Thunell, R.C., Williams. D.F. and Belyea, P.R., 1984. Anoxic events in the Mediterranean Sea in relation to the evolution of Late Neogene climates. Mar. Geol., 59: 105-134.

Thunell, R.C., Rio, R., Sprovieri. R. and Raffi. I., 1991. Limestone-marl couplets: Origin of the Early Pliocene Trubi marls in Calabria. southern Italy. J. Sediment. Petrol., 61: $1109-1122$.

Weltje, G. and De Boer, P.L., 1993. Astronomically induced paleoclimatic oscillations reflected in Pliocene turbidite deposits on Corfu (Greece): Implications for the interpretation of higher order cyclicity in ancient turbidite systems. Geology, 21: 307-310 